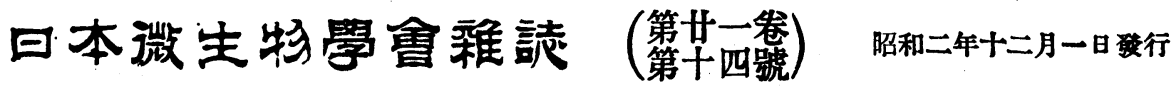

\section{培食基ノ水素いお人濃度ト細菌ノ溫度二 辎スル抵抗力トノ關係二就テ}

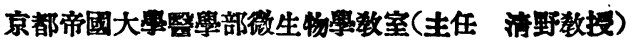

大學院學生 學士 阪 井毅

\begin{tabular}{|c|c|}
\hline & 成 \\
\hline 粕 & 言 \\
\hline 第1章 & 供試材料及賽羷方法 \\
\hline 第2章 & 實驗成綪 \\
\hline 第1節 & 大腸捍菌ノ發育二及ポス影零 \\
\hline 第2節 & 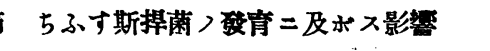 \\
\hline 第3䈣 & 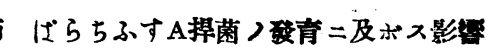 \\
\hline 第4箷 & 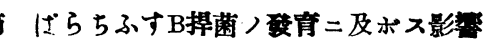 \\
\hline 第5䈱 & 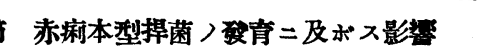 \\
\hline 第6節 & 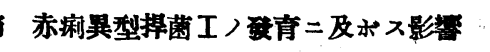 \\
\hline 第7節 & 綠濃捍菌ノ發青二及ホス影留 \\
\hline 第8螌 & 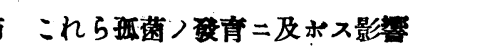 \\
\hline 第9節 & 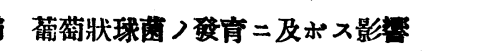 \\
\hline 第3筸 & 概括及結論 \\
\hline & \\
\hline
\end{tabular}

緹官

諸種細菌,發育入培養基,性狀及温度二影響スルュト明カニシテ特二水素い

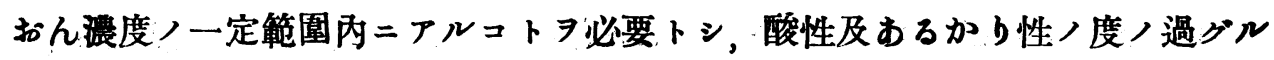
㙁合二小發育セザルノミナラズ逐二死減スルニ至ル，發有スべキ温度二關シテ

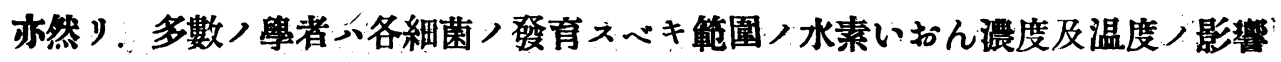
二就テ研究報告 セり.

Miehaelis u. Marcora $(1)$ 》限界水素いおん浱度二就 
加ぶいよん中二培養スルトキッ一定ノ水素いおん漲度二至りラ發育ノ停止スル

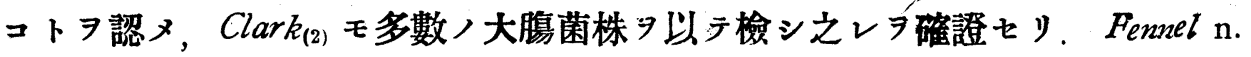
Fisaher $_{(3)}$ 八腸ちぶす桿菌, ばらちふす桿菌, これら弧菌二就テ, Hallu. Fraser $(4)$ 及 Wabbum $_{(5)}$ 八葡霄狀球菌二就テ, 安東及吉岡(6) ハこれら弧菌二就テ培地八水 素いょん濃度ト八關係习研索シテ其發育シ得ル水素いおん濃度ノ範圍。至適水 素いお九濃度及限界水素いお九涱度等习研究報告セり。富永心大腸桿菌/發育 二於ヶル水素いお九濃度卜温度卜ノ關係习研究シ其發育八温度〉上昇スル二從 七其境域狄クナリ，温度降ル時八境域ノ廣マルコトヨ報告セり。

然ルニ水素いおん濃度 $フ$ 異ニセル培養基二發育七ル細菌ノ各種生物學的性状 ニ關スル交献入近時續出スト雖, 少其抵抗力八變化二關スル研究八何レノ學者 ニョリテモ未ダ其發表セラレショ見ズ，余入暴二水素いおん濃度ヨ異ニセル培 養基二發育七ル大腸菌ノ被凝性二就テ研究シタルガ, 本編二於テハ如斯要約 下二發育セル菌ノ温度二對スル抵抗力ノ變化二就テ記述セム卜欲ス。

\section{第 1 章 供試材散及實驗方法}

\section{1. 供試材料}

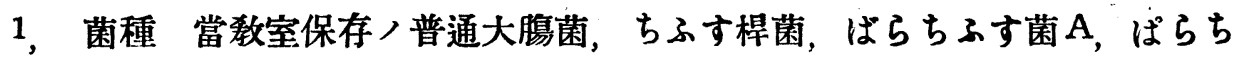
ふす菌 $\mathrm{B}$, 赤淑本型菌, 赤㣜異型菌 I, 綠濃桿菌, これら孤菌及白色葡萄狀球 菌ノ9 種二就テ試驗セリ。

2, 培養基 ぶいよん培養基及中性塞天培養基习使用ス，ぶいよん培養基入 Michaelis ，方法ニョリテ各水素いおん濃度 ヨ定メタル後, 試驗管二分泩シ,

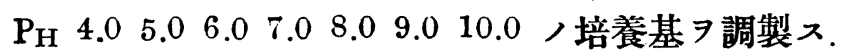

\section{2. 實驗方法}

前記水素いおん濃度 7 異ニセルぶいよん培養基二各種細菌 720 時間培養シ， 其各ぶいよん一白金耳滅菌食監水 5.c.c. 中二浮游混和セシメタル後種々ノ温 度二於テ異りタル時間 $习$ 作用セシメ其一白金耳量 7 中性寒天培養基 7 䄪 $40^{\circ}-$ $45^{\circ} \mathrm{C}=$ 温メ液状トナ七ルモノ二加入混和シ，直二しやーれ二移シ本面培篒トナ

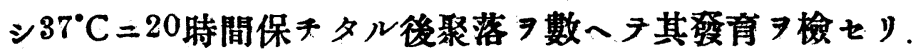




\section{第 2 章實驗 成 精}

以下實驗 二使用シタル各種水素いお九濃度二發育七ル細菌ハ何レモ $60^{\circ} \mathrm{C} 10$ 分 ノ加熱ニョリテ生育セズ.

\section{第 1 節 大腸桿菌ノ發育二及ボス影響}

大第桿菌、PH 4.0 二於テハ發育セズ， ヨリテ $\mathrm{PH} 5.0-10.0$, 間二於テ檢ス 第 1 表ノ如シ.

第 1 表大腸秙菌

\begin{tabular}{|c|c|c|c|c|c|c|c|}
\hline $\begin{array}{l}\text { 永素いおん度 } \\
\text { 濃 }\end{array}$ & 温度c 時間 & 10 分 & 20分 & 30分 & 45分 & 60分 & 120分 \\
\hline PH10.0 & $\begin{array}{l}60^{\circ} \\
55^{\circ} \\
50^{\circ} \\
45^{\circ} \\
40^{\circ}\end{array}$ & $\begin{array}{l}0 \\
0\end{array}$ & & 0 & 0 & $\mathbf{0}$ & $\begin{array}{l}0 \\
0 \\
\infty\end{array}$ \\
\hline PH 9.0 & $\begin{array}{l}60^{\circ} \\
55^{\circ} \\
50^{\circ} \\
45^{\circ} \\
40^{\circ}\end{array}$ & $\begin{array}{l}0 \\
0\end{array}$ & & $\infty$ & 100 & 50 & $\begin{array}{c}0 \\
\text { ca.2000 } \\
\infty\end{array}$ \\
\hline PH 8.0 & $\begin{array}{l}60^{\circ} \\
55^{\circ} \\
50^{\circ} \\
45^{\circ} \\
40^{\circ}\end{array}$ & $\begin{array}{l}0 \\
0\end{array}$ & & $\infty$ & 250 & $\mathbf{1 2 0}$ & $\begin{array}{c}0 \\
\text { ca.2500 } \\
\infty\end{array}$ \\
\hline PH 7.0 & $\begin{array}{l}60^{\circ} \\
55^{\circ} \\
50^{\circ} \\
45^{\circ} \\
40^{\circ}\end{array}$ & $\begin{array}{l}0 \\
0\end{array}$ & & $\infty$ & 1500 & 1200 & $\begin{array}{l}0 \\
\infty \\
\infty\end{array}$ \\
\hline
\end{tabular}




\begin{tabular}{|c|c|c|c|c|c|c|c|}
\hline $\begin{array}{l}\text { 永㨞いおん度 } \\
\text { 遍 }\end{array}$ & 湦度C & 10分 & 20分 & 30分 & 45分 & 60分 & 120分 \\
\hline PH 6.0 & $\begin{array}{l}60^{\circ} \\
55^{\circ} \\
50^{\circ} \\
45^{\circ} \\
40^{\circ}\end{array}$ & $\begin{array}{l}0 \\
0\end{array}$ & & $\infty$ & 15 & 0 & $\begin{array}{c}0 \\
\text { ca.1600 } \\
\infty\end{array}$ \\
\hline PH 5.0 & $\begin{array}{l}60^{\circ} \\
55^{\circ} \\
50^{\circ} \\
45^{\circ} \\
40^{\circ}\end{array}$ & $\begin{array}{l}0 \\
0\end{array}$ & & o & 0 & 0 & $\begin{array}{l}0 \\
0 \\
\infty\end{array}$ \\
\hline
\end{tabular}

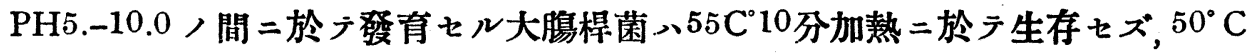
60 分ニデ PH $7.0-9.0$ 二於ヶルモノ、ミ生存ス, 此程度 $ョ$ 低温且短特間二 於テ八PH10.0 及 PH.50 ニ於ヶルモノ 八あるから性 7 增ス二從テ生存菌數少ク, 即, 抵抗力 7 减ジ, 酸性側二於ヶル 方あろから性侧二於ヶルョリモ抵抗力弱シ.

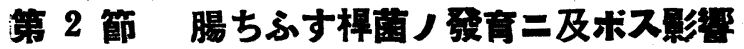

腸ちふす桿菌ハPH40及PH10.0二於テ發育セズ，ヨリテPH50.ー9.0，間二於 テ檢ス。第二表ノ如シ.

第 2 表 腸ちふす桿菌

\begin{tabular}{|c|c|c|c|c|c|c|}
\hline $\begin{array}{ll}\text { 水素いおん } \\
\text { 濃 }\end{array}$ & 温度C & 10分 & 20 分 & 30分 & 60分 & 120分 \\
\hline \multirow{5}{*}{ PH 9.0} & $60^{\circ}$ & 0 & & \multirow{5}{*}{$\infty$} & \multirow{5}{*}{$\mathrm{ca} .600$} & \\
\hline & $55^{\circ}$ & 11 & 0 & & & \\
\hline & $53^{\circ}$ & $\infty$ & 80 & & & \\
\hline & $50^{\circ}$ & & & & & \\
\hline & $45^{\circ}$ & & & & & $\infty$ \\
\hline & $60^{\circ}$ & 0 & & & & \\
\hline
\end{tabular}




\begin{tabular}{|c|c|c|c|c|c|c|}
\hline $\begin{array}{l}\text { 水素いおん } \\
\text { 濃 }\end{array}$ & 温度C 時間 & 10分 & 20分 & 30分 & 60分 & 120分 \\
\hline PH 8.0 & $\begin{array}{l}55^{\circ} \\
53^{\circ} \\
50^{\circ} \\
45^{\circ}\end{array}$ & $\begin{array}{r}\mathrm{ca} 240 \\
\infty\end{array}$ & $\begin{array}{c}0 \\
\text { ca. } 1800\end{array}$ & $\infty$ & $\infty$ & $\infty$ \\
\hline PH 7.0 & $\begin{array}{l}60^{\circ} \\
55^{\circ} \\
53^{\circ} \\
50^{\circ} \\
45^{\circ}\end{array}$ & $\begin{array}{c}0 \\
\text { ca. } 460 \\
\infty\end{array}$ & $\begin{array}{c}0 \\
\text { ca.2700 }\end{array}$ & $\infty$ & : & $\infty$ \\
\hline PH 6.0 & $\begin{array}{l}60^{\circ} \\
55^{\circ} \\
53^{\circ} \\
50^{\circ} \\
45^{\circ}\end{array}$ & $\begin{array}{r}0 \\
0 \\
\text { ca.300 }\end{array}$ & $\begin{array}{c}0 \\
20\end{array}$ & ca. 1200 & ca.300 & $\infty$ \\
\hline PH 5.0 & $\begin{array}{l}60^{\circ} \\
55^{\circ} \\
53^{\circ} \\
50^{\circ} \\
45^{\circ}\end{array}$ & $\begin{array}{r}0 \\
0 \\
\text { ca. } 250\end{array}$ & $\begin{array}{l}0 \\
0\end{array}$ & ca 250 & 30 & ca.3000 \\
\hline
\end{tabular}

PH 5.0-9.0 八間二發育セル腸ちぶす桿菌、55・ 10 分加熱ニティPH 7.0-9.0

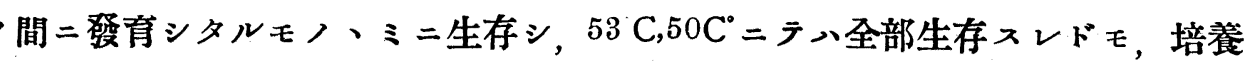

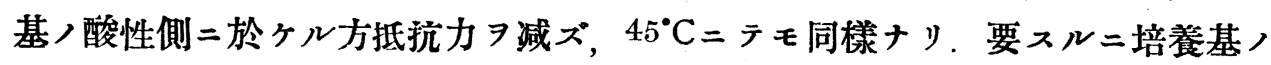
あるから性側及酸性側何レニ進ムモ中性二發育セルモノニ比シテ抵抗力减弱， 度强ク, 殊二酸性側二於ヶルモノ一層其度强シ。

\section{第 3 節 ぱらちふすA菌ノ弡育二及术ス影製}

ぱらちふす $\mathrm{A}$ 菌へ PH, 4.0,及PH10.0 二發育セズ, ヨリテ PH50.ー9.0八間二於 テ檢ス。第 3 表ノ如シ. 
第 3 表 ぱらちふすA桿菌

\begin{tabular}{|c|c|c|c|c|c|c|}
\hline $\begin{array}{l}\text { 永素いおん度 } \\
\end{array}$ & 温度C & 10 分 & 20分 & 30分 & 60分 & 120 分 \\
\hline PH 9.0 & $\begin{array}{l}60^{\circ} \\
55^{\circ} \\
53^{\circ} \\
50^{\circ} \\
45^{\circ}\end{array}$ & $\begin{array}{l}0 \\
0\end{array}$ & 0 & ca.3000 & 120 & $\infty$ \\
\hline PH 8.0 & $\begin{array}{l}60^{\circ} \\
55^{\circ} \\
53^{\circ} \\
50^{\circ} \\
45^{\circ}\end{array}$ & $\begin{array}{c}0 \\
100\end{array}$ & 0 & $\infty$ & $\mathrm{ca} .2500$ & $\infty$ \\
\hline PH 7.0 & $\begin{array}{l}60^{\circ} \\
55^{\circ} \\
53^{\circ} \\
50^{\circ} \\
45^{\circ}\end{array}$ & $\begin{array}{c}0 \\
\text { ca.160 }\end{array}$ & 60 & $\infty$ & $\mathrm{ca}_{6} 6600$ & $\infty$ \\
\hline PH 6.0 & $\begin{array}{l}60^{\circ} \\
55^{\circ} \\
53^{\circ} \\
50^{\circ} \\
45^{\circ}\end{array}$ & $\begin{array}{l}0 \\
0\end{array}$ & 0 & ca. 2700 & ca. 900 & $\infty$ \\
\hline PH 5.0 & $\begin{array}{l}60^{\circ} \\
55^{\circ} \\
53^{\circ} \\
50^{\circ} \\
45^{\circ}\end{array}$ & $\begin{array}{l}0 \\
0\end{array}$ & 0 & 0 & 0 & ca.400 \\
\hline
\end{tabular}

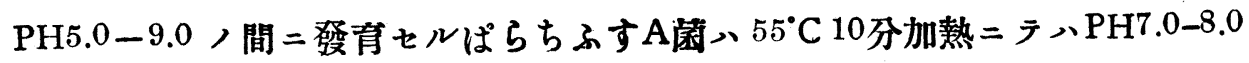
二於テ生存シ, $53^{\circ} \mathrm{C} 20$ 分加熱にテハPH7.0 ニ於ヶルモノノミ生存ス, $5.0^{\circ} \mathrm{C} 30$ 
分及 60 分 $=$ テ PH5.0 二發育セルモノ、ミ死滅ス. $45^{\circ} \mathrm{C} 120$ 分二テハ全部生存 スルモ, $\mathrm{PH} 5.0$ 二於ヶルモノ八抵抗力八减弱七ルョ見ル，酸性及あるから性側 二發育セルモノ、加熱ニョル影響八前闰樣ナリ.

\section{第 4 節 ぱらちふすB菌ノ發育二及ポス影響}

ぱらちふすB菌モPH4.0及 $\mathrm{PH} 10.0$ 二發育セズ、第 4 表ノ如シ.

第 4 表 ぱらちふすB桿菌

\begin{tabular}{|c|c|c|c|c|c|c|}
\hline $\begin{array}{c}\text { 水素いおん } \\
\text { 濃 }\end{array}$ & 温度C 時間 & 10分 & 20分 & 30分 & 60分 & 120 分 \\
\hline PH 9.0 & $\begin{array}{l}60^{\circ} \\
55^{\circ} \\
53^{\circ} \\
50^{\circ} \\
45^{\circ}\end{array}$ & $\begin{array}{c}0 \\
\text { ca. } 200 \\
\infty\end{array}$ & $\begin{array}{r}0 \\
\text { ca. } 400\end{array}$ & $\infty$ & $\cdots$ & $\infty$ \\
\hline PH 8.0 & $\begin{array}{l}60^{\circ} \\
55^{\circ} \\
53^{\circ} \\
50^{\circ} \\
45^{\circ}\end{array}$ & $\begin{array}{r}0 \\
\mathrm{ca} .200 \\
\infty\end{array}$ & $\begin{array}{c}0 \\
\text { ea. } 1000\end{array}$ & $\infty$ & $\infty$ & $\infty$ \\
\hline PH 7.0 & $\begin{array}{l}60^{\circ} \\
55^{\circ} \\
53^{2} \\
50^{\circ} \\
45^{\circ}\end{array}$ & $\begin{array}{c}0 \\
\text { ca.1200 } \\
\infty\end{array}$ & $\begin{array}{c}0 \\
\text { ca. } 2000\end{array}$ & $\infty$ & $\infty$ & $\infty$ \\
\hline PH 6.0 & $\begin{array}{l}60^{\circ} \\
55^{\circ} \\
53^{\circ} \\
50^{\circ} \\
45^{\circ}\end{array}$ & $\begin{array}{l}\mathbf{0} \\
\mathbf{0} \\
\infty\end{array}$ & $\begin{array}{c}0 \\
60\end{array}$ & $\infty$ & $\infty$ & $\infty$ \\
\hline & $\begin{array}{l}60^{\circ} \\
55^{\circ}\end{array}$ & $\begin{array}{l}0 \\
0\end{array}$ & 0 & & & \\
\hline
\end{tabular}




\begin{tabular}{c|c|c|c|c|c|c}
\hline $\begin{array}{c}\text { 水素いお/ } \\
\text { 濃 }\end{array}$ 温度 時間 & 10 分 & 20 分 & 30 分 & 60 分 & 120 分 \\
\hline PH 5.0 & $53^{\circ}$ & 5 & 0 & & & \\
& $50^{\circ}$ & & & ca.200 & & \\
& $45^{\circ}$ & & & & 30 & ca 300
\end{tabular}

PH5・0-10.0 間二發育セルぱらちふす菌 $2.55^{\circ} \mathrm{C} 10$ 分ノ加熱二テPH7.0-9.0 二於ケルモノ、ミ生存ス，即，中性及あるから性二於潑育七ルモノ、ミ生存

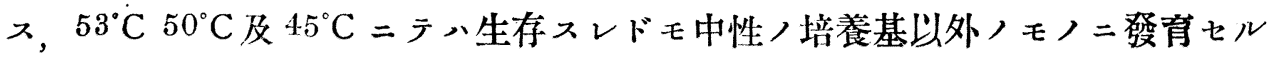
モノ、抵抗力二就テハ前同樣ナリ。

\section{第 5 節 赤蔽本型菌ノ發育二及ボス影響}

赤㾐本型菌 $\mathrm{PH} 4.0$ 及 $\mathrm{PH} 10.0$ 二發育七

第 5 表 赤病本型桿菌

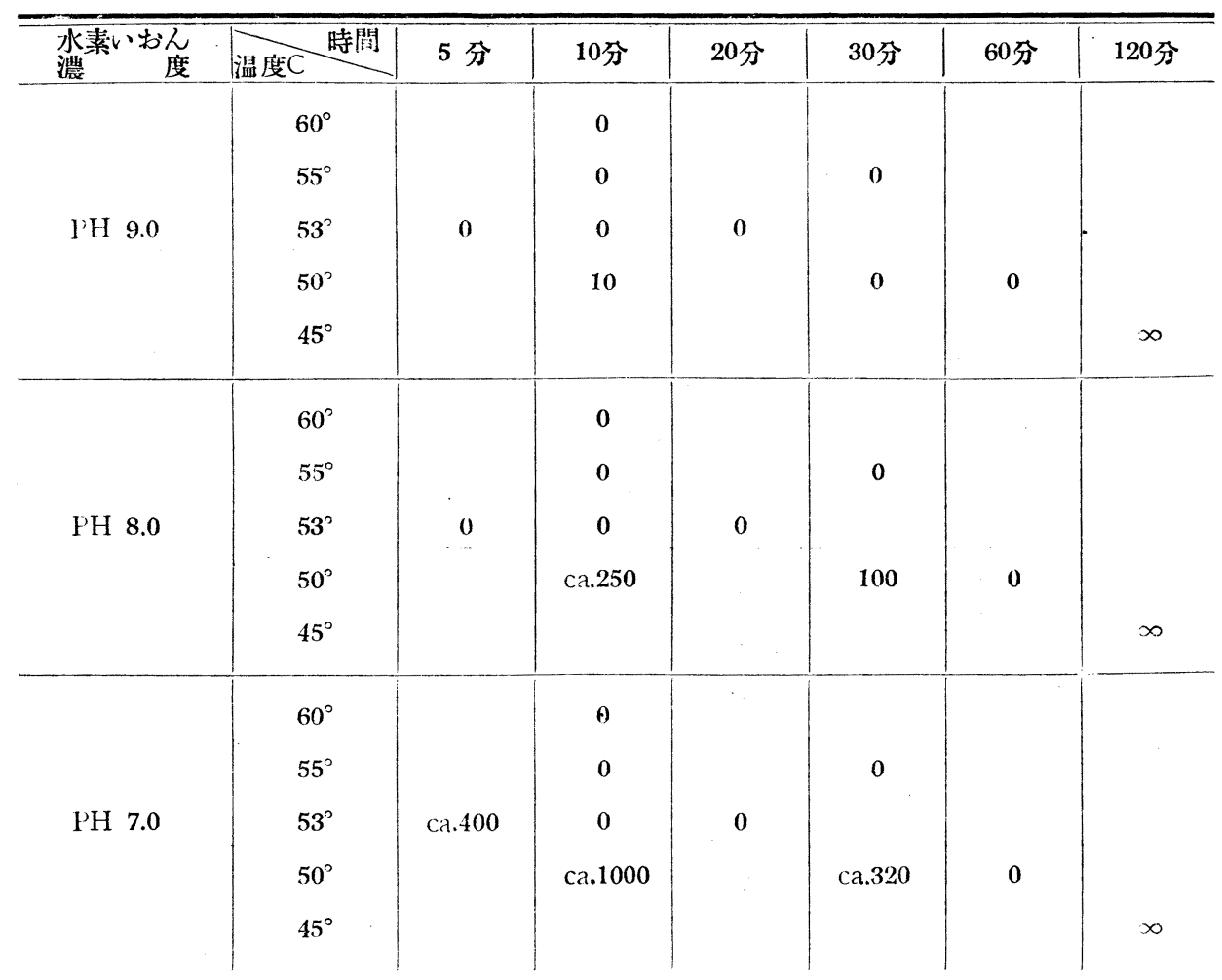




\begin{tabular}{|c|c|c|c|c|c|c|c|}
\hline $\begin{array}{l}\text { 永素いお/ } \\
\text { 摆 }\end{array}$ & 温度C 時間 & 5 分 & 10分 & 20分 & 30分 & 60 分 & 120分 \\
\hline PH 6.0 & $\begin{array}{l}60^{\circ} \\
55^{\circ} \\
53^{\circ} \\
50^{\circ} \\
45^{\circ}\end{array}$ & 70 & $\begin{array}{c}0 \\
0 \\
0 \\
60\end{array}$ & 0 & $\begin{array}{c}0 \\
20\end{array}$ & 0 & $\infty$ \\
\hline PH 5.0 & $\begin{array}{l}60^{\circ} \\
55^{\circ} \\
53^{\circ} \\
50^{\circ} \\
45^{\circ}\end{array}$ & 0 & $\begin{array}{l}0 \\
0 \\
0 \\
0\end{array}$ & 0 & 0 & 0 & $\infty$ \\
\hline
\end{tabular}

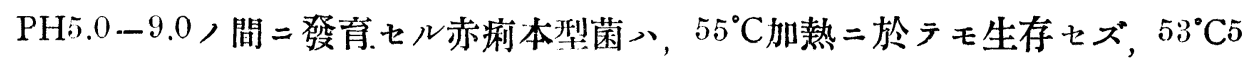
分ニテハPH $6.0-7.0$ 二於ヶルモノ、ミ生存シ， $50^{\circ} \mathrm{C} 10$ 分ニテ $、$ PH5.0 二發育七 ルモノ、ミ死滅シ， $50^{\circ} \mathrm{C} 30$ 分二テハPH5.0及PH9.0 ニ於ヶルモノ死滅ス, $45^{\circ} \mathrm{C}$ 120 分二テハ全部生存ス，酸性及あるかり性側二於テハ前同樣ナリ。

\section{第 6 節 赤㢉異型菌 1 ノ發育二及ボス影響}

赤瘚異型囷 $\mathrm{T}$ 、PH4.0及 $\mathrm{PH} 10.0$ 二於テ發育セズ，第6表ノ如シ.

第 6 表 赤痢異型桿菌. $\mathrm{I}$

\begin{tabular}{|c|c|c|c|c|c|c|c|}
\hline $\begin{array}{l}\text { 水㨞いおん } \\
\text { 濃 度 }\end{array}$ & 温度C 時間 & 5 分 & 10分 & 20分 & 30分 & 60分 & 120 分 \\
\hline \multirow{5}{*}{ PH 9.0} & $60^{\circ}$ & & 0 & \multirow{5}{*}{$\infty$} & & \multirow{5}{*}{$\infty$} & \multirow[b]{5}{*}{$\infty$} \\
\hline & $55^{\circ}$ & & ca. 2400 & & ca. 1800 & & \\
\hline & $53^{\circ}$ & & $\infty$ & & $\infty$ & & \\
\hline & $50^{\circ}$ & & & & $\infty$ & & \\
\hline & $45^{\circ}$ & & & & $\infty$ & & \\
\hline & $60^{\circ}$ & & 0 & & & & \\
\hline & $55^{\circ}$ & & $\infty$ & & ca.1900 & & \\
\hline PH 8.0 & $53^{\circ}$ & & $\infty$ & $\infty$ & $\infty$ & & \\
\hline
\end{tabular}




\begin{tabular}{|c|c|c|c|c|c|c|c|}
\hline $\begin{array}{l}\text { 永素いおん } \\
\text { 濃 }\end{array}$ & 混度C 㭙間 & 5 分 & 10分 & 20 分 & 30分 & 60分 & 120 分 \\
\hline & $\begin{array}{l}50 \text { 。 } \\
45 \text { 。 }\end{array}$ & & & & $\infty$ & $\begin{array}{l}\infty \\
\infty\end{array}$ & $\infty$ \\
\hline PH 7.0 & $\begin{array}{l}60^{\circ} \\
55^{\circ} \\
53^{\circ} \\
50^{\circ} \\
45^{\circ}\end{array}$ & & $\begin{array}{l}0 \\
\infty \\
\infty\end{array}$ & $\infty$ & $\begin{array}{c}\text { ca.2400 } \\
\infty \\
\infty\end{array}$ & $\begin{array}{l}\infty \\
\infty\end{array}$ & $\infty$ \\
\hline PH 6,0 & $\begin{array}{l}60^{\circ} \\
55^{\circ} \\
53^{\circ} \\
50^{\circ} \\
45^{\circ}\end{array}$ & & $\begin{array}{l}0 \\
\infty \\
\infty\end{array}$ & $\infty$ & $\begin{array}{c}\cdot \\
0 \\
50 \\
\infty\end{array}$ & $\begin{array}{l}\infty \\
\infty\end{array}$ & $\infty$ \\
\hline $\mathrm{PH} \quad 5.0$ & $\begin{array}{l}60^{\circ} \\
55^{\circ} \\
53^{\circ} \\
50^{\circ} \\
45^{\circ}\end{array}$ & & $\begin{array}{c}0 \\
0 \\
\text { ca.1500 }\end{array}$ & 40 & $\begin{array}{c}0 \\
0 \\
\text { ca.2000 }\end{array}$ & $\begin{array}{c}\text { ca.1500 } \\
\infty\end{array}$ & $\infty$ \\
\hline
\end{tabular}

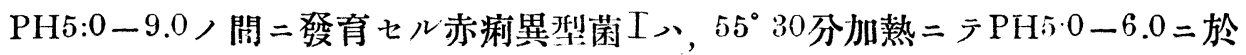

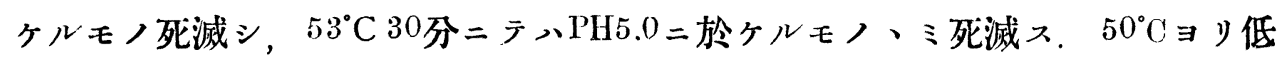
温ニテハ全部發育スレドモ酸性及あるから性側二就テハ前同樣ナリ。

\section{第 7 篩 綠惯桿菌ノ發育二及ホスス影響}

綠濃桿菌ハPH4.0 二於テ發育セズ. 第7表ノ如シ.

第 7 表 綠 漲 桿 菌

\begin{tabular}{|c|c|c|c|c|c|c|}
\hline 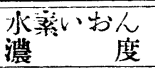 & 温度C 時閪 & 10分 & 20 分 & 30 分 & 30 分 & 120 分 \\
\hline & $\begin{array}{l}60^{\circ} \\
55^{\circ}\end{array}$ & $\begin{array}{c}0 \\
35\end{array}$ & & 0 & & \\
\hline
\end{tabular}


阪

井

数 述

(3091)

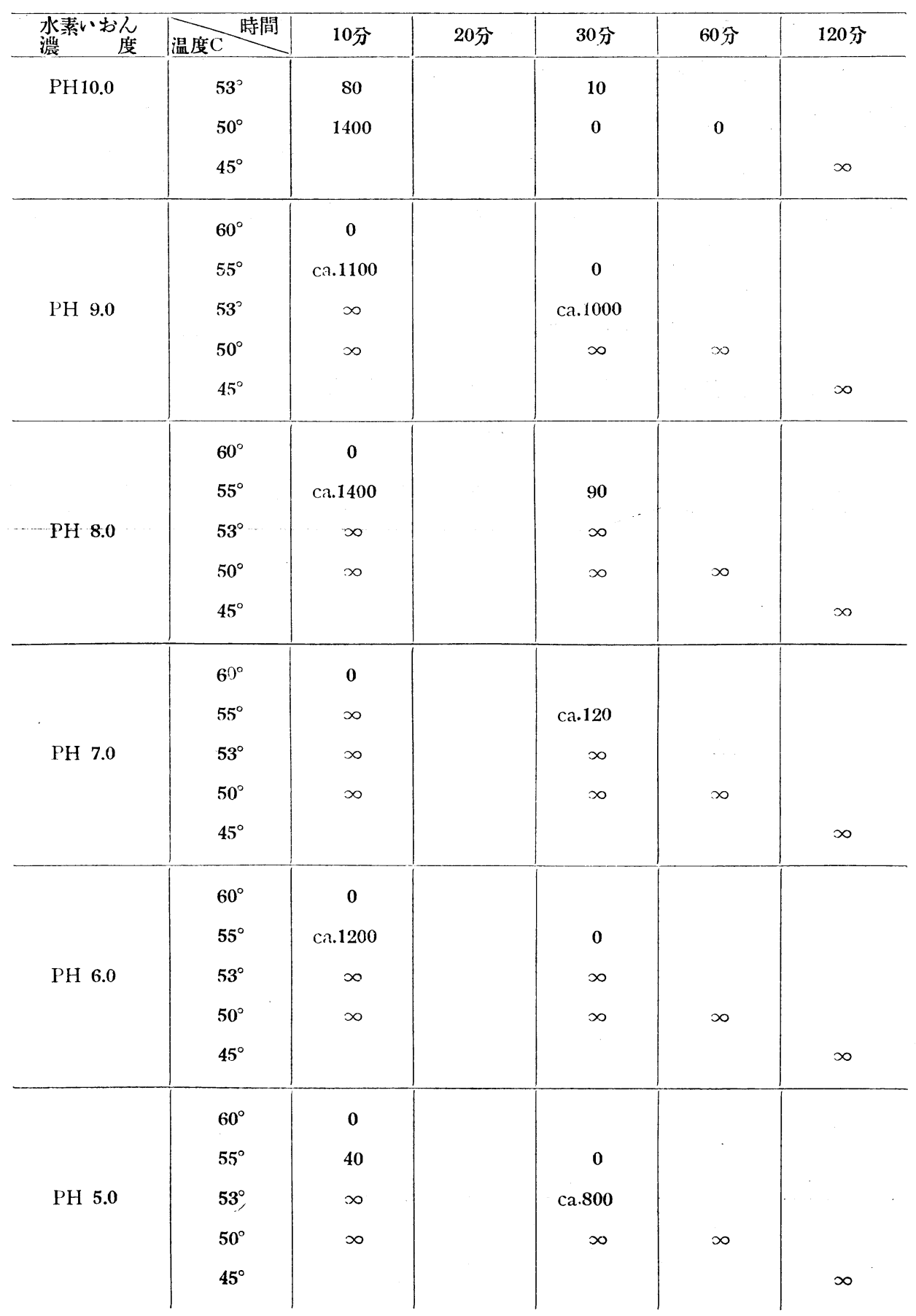


PH5.0-10.0 二發育セル緣浱柦菌 、, $55^{\circ} \mathrm{C} 30$ 分加熱二テハPH7.0-8.0ニ於ヶル モノ、ミ多少生存シ, 53 C 30 分ニテハ全部生存スレドモ酸性及あるかり性側二 於ヶルモ/抵抗力减少シ, $50^{\circ} 60$ 分ニテPH10.0 於ヶルモノ八生存セズ, $45^{\circ} \mathrm{C}$ 120 分 $テ$ 、全部生存ス。 以上ヨリ見レバ綠蜄菌、5 $55^{\circ} \mathrm{C} 30$ 分以上ノ温度及時間 ニテハ生存セズ, 只 $55^{\circ} \mathrm{C} 30$ 分ニテハ至適水素いおん濃度二於ケルモノ、ミ生存 ス酸性及あるかり性側二就テハ前同樣ナリ。

\section{第 8 節 これら弧菌ノ發育ニ及ホス影響}

これら孤菌、PH4.0及 $\mathrm{PH} 10.0$ 二發育七ズ。第8表ノ如 シ.

第 8 表これら弧菌

\begin{tabular}{|c|c|c|c|c|c|c|}
\hline $\begin{array}{l}\text { 水素いまん } \\
\text { 濃 }\end{array}$ & 温度C 時間 & 10分 & 20分 & 30 分 & 60 分 & 120分 \\
\hline PH 9.0 & $\begin{array}{l}60^{\circ} \\
55^{\circ} \\
53^{\circ} \\
50^{\circ} \\
45^{\circ}\end{array}$ & $\begin{array}{l}0 \\
0 \\
0 \\
0\end{array}$ & 0 & 0 & 0 & 2 \\
\hline HP 8.0 & $\begin{array}{l}60^{\circ} \\
55^{\circ} \\
53^{\circ} \\
50^{\circ} \\
45^{\circ}\end{array}$ & $\begin{array}{l}0 \\
0 \\
0 \\
0\end{array}$ & 0 & 0 & 0 & $\infty$ \\
\hline PH 7.0 & $\begin{array}{l}60^{\circ} \\
55^{\circ} \\
53^{\circ} \\
50^{\circ} \\
45^{\circ}\end{array}$ & 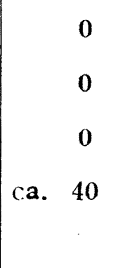 & 0 & 0 & 0 & $\infty$ \\
\hline PH 6.0 & $\begin{array}{l}60^{\circ} \\
55^{\circ} \\
53^{\circ}\end{array}$ & $\begin{array}{l}0 \\
0 \\
0\end{array}$ & & & & \\
\hline
\end{tabular}




\begin{tabular}{|c|c|c|c|c|c|c|}
\hline $\begin{array}{l}\text { 水素いお人 } \\
\text { 濃 犘 }\end{array}$ & 温度C 時閔 & 10分 & 20 分 & 30分 & 60分 & 120 分 \\
\hline & $\begin{array}{l}50^{\circ} \\
45^{\circ}\end{array}$ & 0 & 0 & 0 & 0 & 0 \\
\hline PH 5.0 & $\begin{array}{l}60^{\circ} \\
55^{\circ} \\
53^{\circ} \\
50^{\circ} \\
45^{\circ}\end{array}$ & $\begin{array}{l}0 \\
0 \\
0 \\
0\end{array}$ & 0 & 0 & 0 & 0 \\
\hline
\end{tabular}

PH5.0-9.0 二發育セルこれら弧菌八， $55^{\circ} \mathrm{C}$ 及 $53^{\circ} \mathrm{C}$ 八加熱二モ全ク生存セズ,

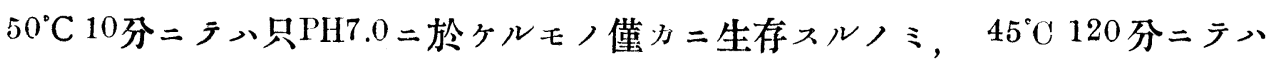
PH5.0-6.0 於ケルモノ死滅シ, PH9.0 於ケルモノ八辛フジラ生存シ, PH7.0 -8.0 二於ケルモノ、ミ多數生存ス。ヨリテ $45^{\circ} \mathrm{C}$ 加熱二テ 八至適濃度二於テ生存 スルモ酸性及あるから性侧二於ヶルモノ八全然死隇ス。

\section{第 9 節，白色葡䓢狀球菌ノ發育二及术ス影響}

白色葡薇狀球菌ハPH4.0 二發育セズ，第 9 表ノ如シ.

第 9 表 白色葡萄狀球菌

\begin{tabular}{|c|c|c|c|c|c|c|}
\hline $\begin{array}{l}\text { 水素いおん } \\
\text { 濃 } \quad \text { 度 }\end{array}$ & 温度C 時間 & 10分 & 20 分 & 30 分 & 60分 & 120分 \\
\hline PH10.0 & $\begin{array}{l}60^{\circ} \\
55^{\circ} \\
50^{\circ} \\
45^{\circ}\end{array}$ & $\begin{array}{c}0 \\
0 \\
15\end{array}$ & $\mathbf{0}$ & $\begin{array}{l}0 \\
0\end{array}$ & 0 & 30 \\
\hline PH 9.0 & $\begin{array}{l}60^{\circ} \\
55^{\circ} \\
50^{\circ} \\
45^{\circ}\end{array}$ & $\begin{array}{l}0 \\
0 \\
\infty\end{array}$ & $\infty$ & $\begin{array}{l}0 \\
0\end{array}$ & 0 & $\infty$ \\
\hline
\end{tabular}




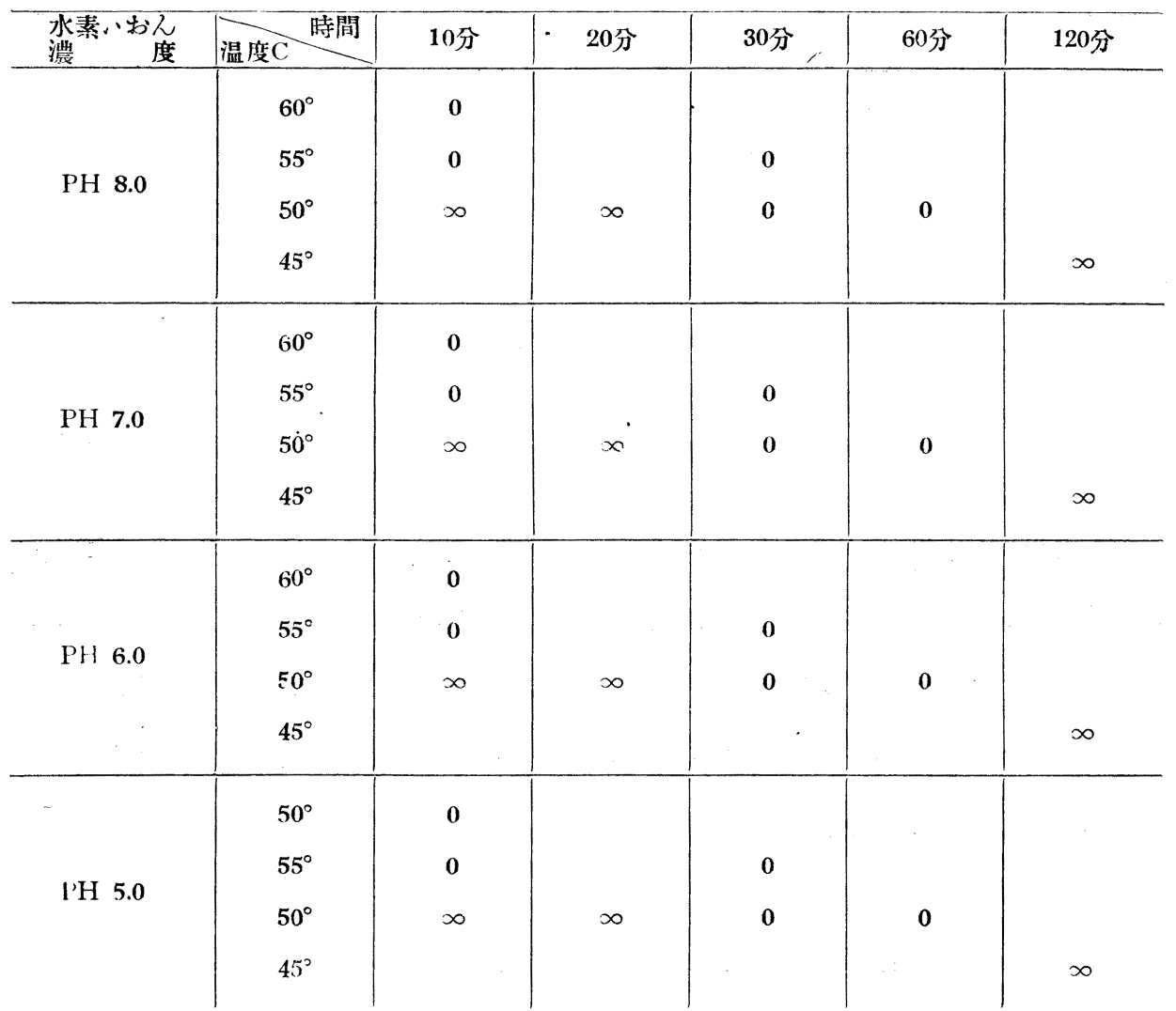

PH5.0-10.0 =發育セル白色葡萄狀球菌、 $55^{\circ} \mathrm{C}$ 及 $50^{\circ} \mathrm{C} 30$ 分加熱ニテハ生存セ ズ， $50^{\circ} \mathrm{C} 20$ 分ニティPH10.0ニ於ヶルセノ、、死滅シ， $50^{\circ} \mathrm{C} 10$ 分及 $45^{\circ} \mathrm{C} 120$ 分二 テハPH10.0 二於ヶルモノ抵抗力减少七ルョ見ル，ヨリテ通覽スル 20 分加熱ニテハ全部生存セルョ見ルナリ.

\section{總 括 及哧 論}

1. 大腸桿菌 $50^{\circ} \mathrm{C} 60$ 分加熱ニテハPH7.0-9.0 /培養基二發育セルモノ生存 シ，同温度同特間以上ニテハ死滅ス，

2. 腸ちふす桿菌、 $55^{\circ} 10$ 分加熱ニテハPH7.0-9.0 ニ於ケルモノ生存スルノ ミニシテ同温度同特間以上二於テハ死滅ス。

3.ぱらちふすA桿菌 $、 53^{\circ} \mathrm{C} 20$ 分加熱ニテハ $\mathrm{PH} 7.0$ 二於ケルモノ、ミ生存シ 
$55^{\circ} \mathrm{C} 10$ 分ニティPH7.0-8.0ニノミ坐存ス。 $50^{\circ} \mathrm{C} 1$ 時間ニテハ $\mathrm{PH} 5.0$ ニ於ケルモノ ミ死滅入.

4.ばらちふすB桿菌、55 10 分加熱ニテPH7.0-9.0ニ於ケルモノミ生存シ, 同温度以下，全部生存ス，但 $53^{\circ} 20$ 分 $=$ テ PH5.0 二於ヶルモノ死滅ス.

5. 赤痢本型桿菌 $、 53^{\circ} \mathrm{C} 5$ 分ニテ $\mathrm{PH} 6,0-7.0$ 二於ヶルモノ、ミ生存シ， $50^{\circ} \mathrm{C}$ 10 分二テハPH5.0 於ケルモ,生存セズ, $50^{\circ} \mathrm{C} 30$ 分ニテハPH5.0及 $\mathrm{PH} 9.0=$ 於ケ ルモノ亦生存セズ.

6. 赤病異型桿菌 $\left[\sim 55^{\circ} \mathrm{C} 30\right.$ 分二テ PH5.0-6.0 於ケルモ，生存セズ, $53^{\circ} \mathrm{C}$ 30 分ニテハPH5.0ニ於ヶルモノ、ミ死滅ス.

7. 綠濃㮛菌 $、 55^{\circ} \mathrm{C} 90$ 分 $=テ \mathrm{PH} 7 .-8.0$ 二於ケルモノ多少生存シ, $50^{\circ} \mathrm{C} 1$ 時間 ニテハPH9.0ニ於ケルモノ、ミ死滅ス。

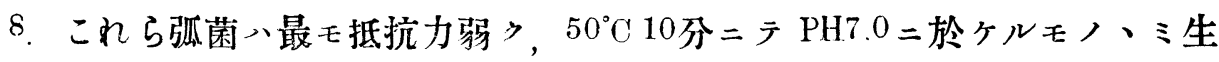
存ス, $45^{\circ} \mathrm{C} 2$ 特間二テモPH5.0-5.0=於ケルモ, 、死隇シ, PH9.0=於ケルモ, ハ辛フジテ生存スルノミナリ。

9 . 白色蔽萄狀球㮛菌 $、 50^{\circ} \mathrm{C} 30$ 分以上ニ於テハ生存セズ, $50^{\circ} \mathrm{C} 20$ 分 $=$ テ $\mathrm{PH}$ 10.0 二於ケルモ, 、ミ死隇ス。

10. 要是一般二細菌ハ温度〉上昇スルニ從テ抵抗力 $\ni$ 减ズ.

11. 酸性及あるから性培養基二發育七ル細菌ハ中性培養基二發育七ルモノニ 比シ温度二對スル抵抗力弱シ.

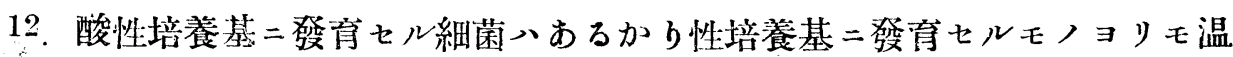
度二對スル抵抗力弱シ。

(完)

\section{文献}

1) Michaelis. L., u. Marcora, F., Zeitschr f. Immunit" t., 1912, 14, S. 170.

2) Clark, W, M., Jour. Biol. chem., 1915. 22. P. 87.

3) Fennel u. Fischer., 

der Bac Toxine Bioch. Z. 129, S. 367; 130. S. 25. 5: 岡田; 白查丙科學，第8然，第2 號，大正9年5月。

6）㽞永; 細菌學，363號，大正15年5月.

7) Michaelis., Seitschr. f. Imm u. nitäf for schung. Bd. 32, 1921.

8）阪井；日本微生物學，第21 卷，第14號. 